\title{
Transformasi Pengaturan Distribusi Urusan Pemerintahan dari Pemerintah Pusat Kepada Pemerintahan Daerah*
}

\author{
Dian Agung Wicaksono**
}

\begin{abstract}
Abstrak
Pasca berlakunya Undang-Undang Nomor 23 Tahun 2014 tentang Pemerintahan Daerah dan Undang-Undang Nomor 6 Tahun 2014 tentang Desa terdapat beberapa hal yang harus dicermati, terlebih dalam hal pengaturan distribusi urusan pemerintahan yang menjadi alas pelaksanaan kewenangan pemerintahan daerah. Apabila dibandingkan dengan UndangUndang Nomor 32 Tahun 2004, maka terdapat perubahan dalam distribusi urusan pemerintahan. Tulisan ini akan memberikan penjelasan terhadap pemahaman mengenai urusan pemerintahan dengan membandingkan dua undang-undang untuk membingkai kerangka pemikiran daerah dalam mengidentifikasi urusan pemerintahan. Pola distribusi urusan pemerintahan dalam politik hukum desentralisasi di Indonesia yang secara simultan melahirkan otonomi daerah, tidak sepatutnya hanya dimaknai sebagai strategi untuk mengelola hubungan kewenangan antara pemerintah pusat dan daerah. Desentralisasi yang sejatinya mendistribusikan urusan harus secara jernih dikaitkan dengan kewenangan sebagai alas pelaksanaan urusan karena konsep kewenangan dalam otonomi daerah tidak bisa ditukar pengertiannya dengan urusan yang kemudian hanya sekedar dimaknai dengan hubungan keuangan, sebagaimana pada rezim Undang-Undang Nomor 23 Tahun 2014 tentang Pemerintahan Daerah.
\end{abstract}

Kata kunci: distribusi, legislasi, pemerintahan daerah, transformasi, urusan pemerintahan.

\section{The Transformation in the Regulation on Distribution of Government Affairs Between Central and Local Governments}

\begin{abstract}
After the enactment of Law Number 23 of 2014 Concerning Local Government and Law Number 6 of 2014 Concerning Village, there are several things to be observed, specifically regarding the regulations on the distribution of government affairs upon which the authority of local government is based. Concerning government affairs, there are several missing aspects in the Law Number 23 of 2014 Concerning Local Government compared to Law Number 32 of 2004 Concerning Local Government. This paper seeks to compare the two regulations to determine the distribution pattern of government affairs in Indonesia's decentralized legal politics that simultaneously spawns local autonomy should not only be interpreted as a strategy to manage the relationship of authority between central and local governments. Decentralization, which genuinely distributes affairs, should be transparently

PADJADJARAN Jurnal IImu Hukum Volume 2 Nomor 3 Tahun 2015 [ISSN 2460-1543] [e-ISSN 2442-9325]

* Tema Tulisan: Sistem Rumah Tangga Daerah dan Hubungan Kewenangan Pusat-Daerah.

** Dosen Fakultas Hukum Universitas Gadjah Mada, Universitas Gadjah Mada, Jl. Sosio Yustitia No. 1 Bulaksumur, Sleman, Yogyakarta, dianagung@ugm.ac.id, S.H., LL.M. (Universitas Gadjah Mada).
\end{abstract}


linked with authority as the legal basis of conducting the affairs and the concept of authority regarding local autonomy should not be simplified into financial matters as regulated by the Law Number 23 of 2014 Concerning Local Government.

Keywords: distribution, legislation, local government, transformation, governmental affairs.

\section{A. Pendahuluan}

Keberadaan Undang-Undang Nomor 23 Tahun 2014 tentang Pemerintahan Daerah (UU Pemda 2014) dan Undang-Undang Nomor 6 Tahun 2014 tentang Desa (UU Desa 2014) memberikan warna baru dalam dinamika pelaksanaan urusan pemerintahan yang dilaksanakan oleh pemerintahan daerah. Mencermati urusan pemerintahan sebagai alas kewenangan pemerintahan daerah, terminologi urusan pemerintahan secara konsisten dipergunakan dalam Undang-Undang Nomor 32 Tahun 2004 tentang Pemerintahan Daerah (UU Pemda 2004) maupun UU Pemda 2014. Lebih lanjut, mekanisme distribusi urusan pemerintahan juga merupakan urusan fundamental untuk ditelaah lebih lanjut.

Hal lain yang harus diperhatikan dalam konteks Negara Kesatuan Republik Indonesia (NKRI) bukan semata urusan pemerintahan dan mekanisme distribusi urusan pemerintahan, namun lebih jauh juga harus diperhatikan pula implikasi dari distribusi urusan pemerintahan yang lebih didangkalkan dalam pengaturan UU Pemda 2014. Berkaitan dengan upaya identifikasi urusan pemerintahan, diketemukan pula urusan yang 'hilang' ketika membandingkan UU Pemda 2004 maupun UU Pemda 2014, sehingga hal ini tentu membawa implikasi terhadap hubungan pusat dan daerah dalam kerangka NKRI. Tulisan ini akan memberikan penjelasan terhadap pemahaman mengenai urusan pemerintahan sebagai alas kewenangan pemerintahan daerah dengan membandingkan antara UU Pemda 2004 maupun UU Pemda 2014.

\section{B. Pembahasan}

1. Distribusi Urusan Pemerintahan dalam Kerangka Negara Kesatuan Republik Indonesia

Bentuk NKRI adalah pilihan bernegara ${ }^{1}$ yang menempatkan kekuasaan berada di

1 Perbincangan mengenai bentuk negara (staat vormen) terkait dengan pilihan-pilihan antara: (a) bentuk negara kesatuan (unitary state, eenheidsstaat); (b) bentuk negara serikat (federalism, bonds-staat); atau (c) bentuk konfederasi (confederation, staten-bond). Pilihan bernegara tersebut dikuatkan dalam kesepakatan dasar Panitia Ad Hoc (PAH) I Majelis Permusyawaratan Rakyat (MPR) dalam melakukan perubahan Undang-Undang Dasar 1945 (UUD 1945), antara lain adalah tetap mempertahankan Negara Kesatuan Republik Indonesia (NKRI). Lampiran Ketetapan MPR Nomor IX/MPR/1999 tentang Penugasan Badan Pekerja Majelis Permusyawaratan Rakyat Republik Indonesia untuk Melanjutkan Perubahan Undang-Undang Dasar Negara Republik Indonesia 
tangan pemerintah pusat, sebagaimana dilegitimasi oleh Pasal 1 ayat (1) UndangUndang Dasar Negara Republik Indonesia Tahun 1945 (UUD 1945). ${ }^{2}$ Prinsip negara kesatuan menjadikan pemegang tampuk kekuasaan tertinggi atas segenap urusan negara adalah pemerintah pusat tanpa suatu delegasi atau pelimpahan kekuasaan kepada pemerintah daerah atau local government. ${ }^{3}$ Namun karena Indonesia menganut asas negara kesatuan yang didesentralisasikan, maka ada tugas-tugas tertentu yang diurus oleh pemerintahan lokal sendiri. ${ }^{4}$

NKRI adalah negara yang bersusunan tunggal, dalam arti bahwa di dalam negara itu tidak ada bagian-bagian daerah yang berstatus negara. Hal ini berarti hanya ada satu negara dan tidak ada negara di dalam negara, hanya ada satu pemerintahan, yaitu pemerintah pusat yang memiliki kekuasaan dan wewenang tertinggi dalam segala lapangan pemerintahan serta hanya memiliki satu undang-undang dasar. ${ }^{5}$ Desain negara kesatuan menempatkan kekuasaan pemerintah pusat dominan dalam menjaga bahtera kehidupan berbangsa dan bernegara, sehingga wajar di awal masa kemerdekaan nuansa sentralistik begitu kuat sebagai konsekuensi logis adanya paham kekuasaan yang tersentral.

Prinsip yang terkandung pada negara kesatuan menjadikan pemegang tampuk kekuasaan tertinggi atas segenap urusan negara adalah pemerintah pusat (central government) tanpa adanya gangguan oleh suatu delegasi atau pelimpahan kekuasaan kepada pemerintah daerah (local government). Selain itu, terdapat asas bahwa segenap urusan-urusan negara tidak dibagi antara pemerintah pusat (central government) dengan pemerintah daerah (local government) sedemikian rupa sehingga urusan-urusan negara kesatuan tetap merupakan suatu kebulatan (eenheid) dan bahwa pemegang kekuasaan tertinggi di negara itu ialah pemerintah pusat. ${ }^{6}$ Pemahaman itulah yang menyebabkan pertentangan antara pemerintah pusat dan pemerintah daerah tak kunjung selesai. Di sini pulalah letak kemungkinan spanning yang timbul dari kondisi tarik-menarik antara kedua kecenderungan tersebut. ${ }^{7}$

Dalam konteks negara yang luas secara geografis, biasanya dimunculkan mekanisme untuk mempermudah pelayanan publik dengan konsep distribusi

Tahun 1945. Lihat dalam Jimly Asshiddiqie, Konstitusi dan Konstitusionalisme, Jakarta: Konstitusi Press, 2006, hlm. 381.

2 Pasal 1 ayat (1) UUD 1945, "Negara Indonesia ialah Negara Kesatuan, yang berbentuk Republik."

3 M. Solly Lubis, Pergeseran Garis Politik dan Perundang-undangan Mengenai Pemerintah Daerah, Bandung: Alumni, 1983, hlm. 8.

4 Ni'matul Huda, Otonomi Daerah: Filosofi, Sejarah Perkembangan dan Problematika, Yogyakarta: Pustaka Pelajar, 2005, hlm. 55.

5 Soehino, Hukum Tata Negara Perkembangan Otonomi Daerah, Yogyakarta: BPFE, 2004, hlm. 175.

6 F. Soegeng Istanto, Beberapa Segi Hubungan Pemerintah Pusat dan Daerah dalam Negara Kesatuan Indonesia, Yogyakarta: Karyaputera, 1971, hlm. 16.

7 Bagir Manan, Perjalanan Historis Pasal 18UUD 1945, Jakarta: Uniska, 1993, hlm. 3. 
urusan pemerintahan dari pusat kepada daerah. Dalam perspektif yang lain, distribusi urusan pemerintahan inilah yang melahirkan adanya otonomi bagi daerah dalam mengelola urusan yang telah diberikan. Lebih lanjut, Juniarto menjelaskan bahwa luas sempitnya urusan-urusan yang diserahkan kepada suatu pemerintah lokal yang berhak mengatur dan mengurus rumah tangganya sendiri, tergantung pada politik hukum yang dianut pada waktu itu, yang dituangkan dalam hukum positif. $^{8}$

Berangkat dari pemikiran tersebut, terjadi distribusi urusan dari pemerintah pusat kepada pemerintah daerah yang semata-mata dilaksanakan untuk mendekatkan pelayanan publik kepada masyarakat. Berdasarkan distribusi urusan tersebut, daerah diberi kewenangan untuk mengatur dan mengelola sendiri potensi daerahnya. Distribusi urusan inilah yang berimplikasi pada munculnya otonomi pada daerah yang terus mengalami perkembangan. Namun, perkembangan politik desentralisasi ${ }^{9}$ di Indonesia belum sejalan dengan peningkatan kesejahteraan masyarakat di daerah.

Desain konstitusi terkait distribusi urusan pemerintahan ini telah secara definitif dituangkan dalam UUD 1945 yang menyatakan, "Pemerintahan daerah provinsi, daerah kabupaten, dan kota mengatur dan mengurus sendiri urusan pemerintahan menurut asas otonomi dan tugas pembantuan." ${ }^{10}$ Pengaturan tersebut memberikan kejelasan bahwa pelaksana urusan pemerintahan adalah provinsi dan kabupaten/kota, selain tentu saja Kementerian Negara." (huruf tebal oleh penulis)

\section{Problematika Definisi Desentralisasi, Dekonsentrasi, dan Tugas Pembantuan}

Hal lain yang sejatinya harus diperhatikan secara serius adalah terkait definisi

8 Juniarto, Perkembangan Pemerintah Lokal, Bandung: Alumni, 1967, hlm. 30.

9 Dalam konteks sejarah, politik desentralisasi telah beberapa kali mengalami perubahan desain, sejalan dengan perubahan prinsip yang digunakan, seperti: (a) prinsip rumah tangga material (ultra vires) yang dianut UndangUndang Nomor 1 Tahun 1945 tentang Peraturan Mengenai Kedudukan Komite Nasional (UU 1/1945) dan Undang-Undang Nomor 22 Tahun 1948 tentang Penetapan Aturan-Aturan Pokok Mengenai Pemerintahan Sendiri di Daerah-Daerah yang Berhak Mengatur dan Mengurus Rumah Tangganya Sendiri (UU Pemda 1948); (b) prinsip rumah tangga formal (general competence) dengan variasinya, yaitu otonomi riil dan seluas-luasnya seperti yang dianut Undang-Undang Nomor 1 Tahun 1957 tentang Pokok-Pokok Pemerintahan Daerah (UU Pemda 1957), Penetapan Presiden Nomor 6 Tahun 1959 tentang Pemerintahan Daerah (Penpres 6/1959) disempurnakan, Penetapan Presiden Nomor 5 Tahun 1960 tentang Dewan Perwakilan Rakyat Daerah Gotong Royong dan Sekretariat Daerah (Penpres 5/1960) disempurnakan, Undang-Undang Nomor 18 Tahun 1965 tentang Pokok-Pokok Pemerintahan Daerah (UU Pemda 1965), Undang-Undang Nomor 22 Tahun 1999 tentang Pemerintahan Daerah (UU Pemda 1999), Undang-Undang Nomor 32 Tahun 2004 tentang Pemerintahan Daerah (UU Pemda 2004), dan Undang-Undang Nomor 23 Tahun 2014 tentang Pemerintahan Daerah (UU Pemda 2014); serta (c) prinsip otonomi yang nyata dan bertanggungjawab sebagaimana yang dianut Undang-Undang Nomor 5 Tahun 1974 tentang Pokok-Pokok Pemerintahan di Daerah (UU Pemda 1974). Lihat dalam Pratikno, et.al., Policy Brief Menata Ulang Desain Desentralisasi Indonesia, Yogyakarta: Program Pascasarjana S2 Politik dan Pemerintahan, Jurusan Politik dan Pemerintahan, Fakultas Ilmu Sosial dan Ilmu Politik, Universitas Gadjah Mada, 2010, hlm. 1.

10 Pasal 18 ayat (2) UUD 1945. 
desentralisasi, dekonsentrasi, dan tugas pembantuan. Dalam rangka mempermudah pemahaman, berikut adalah persandingan definisi ketiga pola pelimpahan urusan pemerintahan di atas, yaitu:

\section{Tabel 1. Persandingan Definisi Desentralisasi, Dekonsentrasi, dan Tugas Pembantuan}

\begin{tabular}{|c|c|c|}
\hline Terminologi & Rezim UU Pemda 2004 & Rezim UU Pemda 2014 \\
\hline Desentralisasi & $\begin{array}{l}\text { Desentralisasi adalah } \\
\text { penyerahan wewenang } \\
\text { pemerintahan oleh Pemerintah } \\
\text { kepada daerah otonom untuk } \\
\text { mengatur dan mengurus urusan } \\
\text { pemerintahan dalam Sistem } \\
\text { Negara Kesatuan Republik } \\
\text { Indonesia. }\end{array}$ & $\begin{array}{l}\text { Desentralisasi adalah penyerahan Urusan } \\
\text { Pemerintahan oleh Pemerintah Pusat } \\
\text { kepada daerah otonom berdasarkan Asas } \\
\text { Otonomi. }\end{array}$ \\
\hline Dekonsentrasi & $\begin{array}{l}\text { Dekonsentrasi adalah } \\
\text { pelimpahan wewenang } \\
\text { pemerintahan oleh Pemerintah } \\
\text { kepada Gubernur sebagai wakil } \\
\text { pemerintah dan/atau kepada } \\
\text { instansi vertikal di wilayah } \\
\text { tertentu. }\end{array}$ & $\begin{array}{l}\text { Dekonsentrasi adalah pelimpahan } \\
\text { sebagian Urusan Pemerintahan yang } \\
\text { menjadi kewenangan Pemerintah Pusat } \\
\text { kepada gubernur sebagai wakil } \\
\text { Pemerintah Pusat, kepada instansi } \\
\text { vertikal di wilayah tertentu, dan/atau } \\
\text { kepada gubernur dan bupati/wali kota } \\
\text { sebagai penanggung jawab urusan } \\
\text { pemerintahan umum. }\end{array}$ \\
\hline $\begin{array}{l}\text { Tugas } \\
\text { Pembantuan }\end{array}$ & $\begin{array}{l}\text { Tugas pembantuan adalah } \\
\text { penugasan dari Pemerintah } \\
\text { kepada daerah dan/ atau desa } \\
\text { dari pemerintah provinsi kepada } \\
\text { kabupaten/kota dan/atau desa } \\
\text { serta dari pemerintah } \\
\text { kabupaten/kota kepada desa } \\
\text { untuk melaksanakan tugas } \\
\text { tertentu. }\end{array}$ & $\begin{array}{l}\text { Tugas Pembantuan adalah penugasan } \\
\text { dari Pemerintah Pusat kepada daerah } \\
\text { otonom untuk melaksanakan sebagian } \\
\text { Urusan Pemerintahan yang menjadi } \\
\text { kewenangan Pemerintah Pusat atau dari } \\
\text { Pemerintah Daerah provinsi kepada } \\
\text { Daerah kabupaten/kota untuk } \\
\text { melaksanakan sebagian Urusan } \\
\text { Pemerintahan yang menjadi kewenangan } \\
\text { Daerah provinsi. }\end{array}$ \\
\hline
\end{tabular}

Berdasarkan persandingan di atas, terdapat beberapa hal yang harus diperhatikan, yaitu: pertama, pada UU Pemda 2014 secara konsisten mendefinisikan desentralisasi, dekonsentrasi, dan tugas pembantuan dengan menggunakan frasa 'urusan pemerintahan', yang berarti pembentuk undangundang menyadari betul bahwa objek hubungan pusat dan daerah adalah urusan pemerintahan. Hal ini tentu menjadi berbeda bila dibandingkan dengan definisi pada UU Pemda 2004 yang memerlukan perhatian lebih untuk mengetahui bahwa obyek utama dari hubungan pusat dan daerah adalah urusan pemerintahan. Hal yang harus ditelisik lebih jauh adalah alasan di balik perbedaan pengaturan rezim UU Pemda 2004 dan UU Pemda 2014 dalam memaknai urusan pemerintahan. 
Pada UU Pemda 2004, urusan pemerintahan hanya diletakkan dalam definisi pemerintahan daerah, ${ }^{11}$ otonomi daerah, ${ }^{12}$ dan daerah otonom. ${ }^{13} \mathrm{Hal}$ ini tentu berbeda dengan pengaturan dalam UU Pemda 2014 yang memberikan nomenklatur urusan pemerintahan dengan definisi:

"Urusan Pemerintahan adalah kekuasaan pemerintahan yang menjadi kewenangan Presiden yang pelaksanaannya dilakukan oleh kementerian negara dan penyelenggara Pemerintahan Daerah untuk melindungi, melayani, memberdayakan, dan menyejahterakan masyarakat."14

Pendefinisian tersebut tentu menjadi peneguhan bahwa pelaksana urusan pemerintahan adalah kementerian negara dan penyelenggara pemerintahan daerah. Hal ini juga sejalan dengan UUD 1945 yang memang hanya menyematkan urusan pemerintahan pada dua lembaga tersebut. Berdasarkan hal tersebut, maka konsekuensi yang seharusnya terjadi adalah tidak boleh ada pengaturan lain di bawah konstitusi yang mampu menyematkan urusan pemerintahan kepada lembaga lain selain kementerian negara dan penyelenggara pemerintahan daerah.

Namun hal tersebut diterobos oleh UU Desa dengan menyematkan urusan pemerintahan kepada desa. Hal tersebut dengan jelas dapat diketemukan pada pendefinisian dalam UU Desa, yaitu: ${ }^{15}$

1. Desa adalah desa dan desa adat atau yang disebut dengan nama lain, selanjutnya disebut Desa, adalah kesatuan masyarakat hukum yang memiliki batas wilayah yang berwenang untuk mengatur dan mengurus urusan pemerintahan, kepentingan masyarakat setempat berdasarkan prakarsa masyarakat, hak asal usul, dan/atau hak tradisional yang diakui dan dihormati dalam sistem pemerintahan Negara Kesatuan Republik Indonesia.

2. Pemerintahan Desa adalah penyelenggaraan urusan pemerintahan dan kepentingan masyarakat setempat dalam sistem pemerintahan Negara Kesatuan Republik Indonesia. (huruf tebal oleh penulis)

Permasalahan fatal UU Desa di atas semakin diperkuat bila dibandingkan dengan Pasal 18 ayat (2) UUD 1945 yang disebutkan bahwa penyelenggara urusan pemerintahan adalah pemerintahan daerah, sehingga dengan mudah dapat dipertanyakan apakah desa mempunyai pemerintahan daerah atau tidak. Dengan demikian, tidak seharusnya desa melaksanakan urusan pemerintahan. Problematika definisi yang dihadirkan oleh UU Desa memiliki implikasi dan risiko yuridis yang serius. Bila kemudian berkaca pada praktik UU Nomor 27 Tahun 2004 tentang Komisi Kebenaran dan Rekonsiliasi (UU KKR). Undang-undang ini dibatalkan

11 Pasal 1 angka 2 UU Pemda 2004.

12 Pasal 1 angka 5 UU Pemda 2004.

13 Pasal 1 angka 6 UU Pemda 2004.

14 Pasal 1 angka 5 UU Pemda 2004.

15 Pasal 1 angka 1 dan 2 Undang-Undang Nomor 6 Tahun 2014 tentang Desa (UU Desa 2014). 
oleh Mahkamah Konstitusi (MK) karena masalah definisi dalam ketentuan umum yang diujikan. ${ }^{16}$

Kedua, definisi dekonsentrasi pada UU Pemda 2014 menjernihkan asal urusan pemerintahan dan memperluas lingkup penerima pelimpahan urusan pemerintahan. Dalam definisi dekonsentrasi pada UU Pemda 2014 terlihat jelas asal urusan pemerintahan yang dilaksanakan oleh daerah merupakan urusan pemerintahan yang menjadi kewenangan pemerintah pusat. Bila merujuk pada UU Pemda 2014, maka urusan yang dimaksud adalah urusan pemerintahan absolut, ${ }^{17}$ urusan pemerintahan konkuren, ${ }^{18}$ dan urusan pemerintahan umum. ${ }^{19}$ Pemerintah pusat dengan ketiga urusan pemerintahan tersebut dapat melimpahkan sebagian kepada daerah, dimana sebagian urusan yang lain harus tetap diatur dan diurus oleh pemerintah pusat.

Selain itu, pendefinisian di atas juga memperluas pihak penerima limpahan urusan pemerintahan, yaitu: (a) gubernur sebagai wakil pemerintah pusat; (b) instansi vertikal di wilayah tertentu; dan/atau (c) gubernur dan bupati/wali kota sebagai penanggung jawab urusan pemerintahan umum. ${ }^{20} \mathrm{Hal}$ ini tentu lebih luas dari yang semula hanya: (a) gubernur sebagai wakil pemerintah; dan/atau (b) instansi vertikal di wilayah tertentu. ${ }^{21}$ Dalam definisi baru ini berarti kabupaten/kota saat ini dapat dilimpahi dekonsentrasi, walaupun dalam koridor urusan pemerintahan umum.

Ketiga, pendefinisian tugas pembantuan pada UU Pemda 2014 menjernihkan asal tugas dan mempersempit lingkup penerima tugas. Definisi tugas pembantuan pada UU Pemda 2014 menegaskan bahwa tugas pembantuan diadakan dalam rangka melaksanakan sebagian urusan pemerintahan yang notabene hal ini tidak disebutkan secara definitif pada UU Pemda 2004. Lingkup penerima tugas pembantuan semula dimungkinkan diberikan kepada: (a) dari pemerintah kepada daerah dan/atau desa; (b) dari pemerintah provinsi kepada kabupaten/kota dan/atau desa; serta (c) dari pemerintah kabupaten/kota kepada desa. ${ }^{22}$ Dalam pengaturan UU Pemda 2014, tugas pembantuan hanya dapat diberikan kepada: (a) dari pemerintah pusat kepada daerah otonom; dan (b) dari pemerintah daerah

16 Putusan Mahkamah Konstitusi Nomor 006/PUU-IV/2006 tentang Pengujian Undang-Undang Nomor 27 Tahun 2004 tentang Komisi Kebenaran dan Rekonsiliasi terhadap UUD1945.

17 Pasal 9 ayat (2) UU Pemda 2014: “Urusan pemerintahan absolut adalah Urusan Pemerintahan yang sepenuhnya menjadi kewenangan Pemerintah Pusat".

18 Pasal 9 ayat (3) UU Pemda 2014: "Urusan pemerintahan konkuren adalah Urusan Pemerintahan yang dibagi antara Pemerintah Pusat dan Daerah provinsi dan Daerah kabupaten/kota". Hal ini berarti juga merupakan urusan pemerintahan Pemerintah Pusat.

19 Pasal 9 ayat (5) UU Pemda 2014: “Urusan pemerintahan umum adalah Urusan Pemerintahan yang menjadi kewenangan Presiden sebagai kepala pemerintahan".

20 Pasal 1 angka 9 UU Pemda 2014.

21 Pasal 1 angka 8 UU Pemda 2004.

22 Pasal 1 angka 9 UU Pemda 2004. 
provinsi kepada daerah kabupaten/kota. ${ }^{23}$ Dengan demikian, desa tidak lagi dimungkinkan untuk menerima tugas pembantuan.

Namun demikian, haruslah dicermati pula pengaturan dalam UU Desa yang memberikan kewenangan-kewenangan kepada desa sebagai berikut: ${ }^{24}$

a. kewenangan berdasarkan hak asal usul;

b. kewenangan lokal berskala desa;

c. kewenangan yang ditugaskan oleh pemerintah, pemerintah daerah provinsi, atau pemerintah daerah kabupaten/kota; dan

d. kewenangan lain yang ditugaskan oleh pemerintah, pemerintah daerah provinsi, atau pemerintah daerah kabupaten/kota sesuai dengan ketentuan peraturan perundang-undangan.

Bila kemudian mencermati implikasi dari pengaturan di atas, maka menjadi pertanyaan, tugas apa yang dimaksud dengan 'kewenangan yang ditugaskan', karena seharusnya penugasan hanya mungkin dilakukan melalui metode distribusi tugas pembantuan. Bila iya, maka menjadi pertentangan serius mengingat UU Pemda 2014 menggariskan dengan teramat jelas bahwa desa bukanlah penerima tugas pembantuan. Di sisi yang lain, harus dipahami dengan baik bahwa yang dilaksanakan dalam tugas pembantuan adalah urusan pemerintahan, sedangkan urusan pemerintahan hanya dilaksanakan oleh kementerian negara dan penyelenggara pemerintahan daerah. Dengan demikian, menjadi semakin jelas bahwa desa yang tidak masuk diantara kedua nomenklatur tersebut mutatis mutandis tidak diperkenankan melaksanakan tugas pembantuan.

Hal lain yang harus diperhatikan dalam konteks tugas pembantuan adalah apakah diperbolehkan pemberian penugasan dari pemerintah daerah provinsi kepada daerah kabupaten/kota. Hal tersebut dikarenakan menurut konstitusi, "Pemerintahan daerah provinsi, daerah kabupaten, dan kota mengatur dan mengurus sendiri urusan pemerintahan menurut asas otonomi dan tugas pembantuan" 25 (huruf tebal oleh penulis). Bukankah seharusnya pemerintahan daerah provinsi, daerah kabupaten, dan kota harus melaksanakan sendiri urusan pemerintahan berdasarkan kewenangan yang ditugaskan oleh pemerintah pusat dan tidak diperkenankan untuk menugaskan kembali ke satuan pemerintahan di bawahnya. Hal ini sesuai dengan prinsip bahwa urusan-urusan negara kesatuan tetap merupakan suatu kebulatan (eenheid) dan pemegang kekuasaan tertinggi di negara itu ialah pemerintah pusat. ${ }^{26}$ Keberadaan frasa 'menurut asas otonomi dan tugas pembantuan' merupakan mekanisme yang dipergunakan pemerintah pusat untuk menugaskan kewenangan melaksanakan urusan pemerintahan kepada

\footnotetext{
23 Pasal 1 angka 11 UU Pemda 2014.

24 Pasal 19 UU Desa 2014.

25 Pasal 18 ayat (2) UUD 1945.

${ }^{26}$ F. Soegeng Istanto, Loc.cit.
} 
pemerintahan daerah provinsi, daerah kabupaten, dan kota, dan bukanlah mekanisme yang untuk menugaskan pelaksanaan urusan pemerintahan dari pemerintah daerah provinsi kepada daerah kabupaten/kota.

Keempat, terdapat potensi inkonstitusionalitas pendefinisian desentralisasi pada UU Pemda 2014 dan pertentangannya dengan materi muatan UU Pemda 2014. Pemikiran mengenai potensi inkonstitusionalitas didasari dari rumusan definisi desentralisasi dalam UU Pemda 2014, yaitu “... penyerahan Urusan Pemerintahan oleh Pemerintah Pusat kepada daerah otonom ..." ${ }^{27}$ (huruf tebal oleh penulis). Perlu diperhatikan mengenai penggunaan diksi 'penyerahan' karena konstitusi hanya memandatkan daerah untuk mengatur dan mengurus sendiri urusan pemerintahan tanpa pemaparan eksplisit penyerahan urusan pemerintahan dalam konteks NKRI. Berbekal pemahaman bahwa dalam prinsip negara kesatuan pemegang tampuk kekuasaan tertinggi atas segenap urusan negara ialah pemerintah pusat (central government), sedemikian rupa sehingga urusan-urusan negara kesatuan tetap merupakan suatu kebulatan (eenheid) dan bahwa pemegang kekuasaan tertinggi di negara itu ialah pemerintah pusat, ${ }^{28}$ maka seharusnya urusan pemerintahan tetap dalam satu kesatuan dimiliki pemerintah pusat.

Apabila urusan pemerintahan hendak dilaksanakan oleh daerah, maka yang diserahkan cukup kewenangan untuk melaksanakan urusan pemerintahan, dan bukan urusan pemerintahannya yang diserahkan. Dengan demikian, diksi 'penyerahan' menjadi tidak tepat. Berdasarkan pendekatan linguistik pun, penyerahan memiliki suasana kebatinan yang berbeda dengan pelimpahan. Penyerahan maknanya adalah proses, cara, perbuatan memberikan, menyampaikan, memberikan dengan penuh kepercayaan, dan memasrahkan ${ }^{29}$. Pelimpahan bermakna proses, cara, perbuatan melimpahkan (memindahkan) hak, dan wewenang. ${ }^{30}$ Dengan demikian, diksi yang lebih tepat dengan konsep negara kesatuan yang mengusung kebulatan kekuasaan pemerintahan adalah 'pelimpahan urusan' dan bukan 'penyerahan urusan'.

Diksi 'pelimpahan' lebih tepat karena hanya terkait wewenang dan bukan keseluruhan. Frasa 'pelimpahan urusan' atau 'penyerahan wewenang' lebih tepat digunakan karena sejalan dengan prinsip dasar negara kesatuan. Definisi yang lebih tepat justru adalah definisi desentralisasi pada UU Pemda 2004 yang menyatakan, "Desentralisasi adalah penyerahan wewenang pemerintahan oleh Pemerintah kepada daerah otonom untuk mengatur dan mengurus urusan pemerintahan dalam Sistem Negara Kesatuan Republik Indonesia." ${ }^{\prime 1}$

\footnotetext{
27 Pasal 1 angka 8 UU Pemda 2014.

28 F. Soegeng Istanto, Loc.cit.

${ }^{29}$ Tim Penyusun, Kamus Bahasa Indonesia, Jakarta: Pusat Bahasa Departemen Pendidikan Nasional, 2008, hlm. 1325.

30 Ibid., hlm. 863.

31 Pasal 1 angka 7 UU Pemda 2004.
} 
Adapun terkait pertentangan definisi tersebut dengan materi muatan UU Pemda 2014 terlihat dari frasa 'penyerahan urusan pemerintahan' dengan klasifikasi urusan pemerintahan yang diatur dalam UU Pemda 2014. Bila memang desentralisasi dimaknai sebagai bentuk penyerahan urusan pemerintahan, maka menjadi kontradiktif dengan urusan pemerintahan konkuren yang dimaknai sebagai urusan pemerintahan yang dibagi antara pemerintah pusat, daerah provinsi, dan daerah kabupaten/kota. Hal ini adalah contradictio in terminis, karena urusan yang sudah diserahkan oleh pemerintah pusat ternyata masih dibagi lagi dengan pemerintah pusat. Terlebih kemudian bila dicermati Lampiran UU Pemda secara definitif melakukan pembagian urusan pemerintahan konkuren antara pemerintah pusat, daerah provinsi, dan daerah kabupaten/kota. Hal ini menunjukkan terdapat pertentangan pengaturan di dalam UU Pemda 2014.

\section{Dinamika Pengaturan Distribusi Urusan Pemerintahan}

Hal lain yang harus dicermati adalah terkait identifikasi urusan pemerintahan yang 'hilang' ketika membandingkan UU Pemda 2004 dan UU Pemda 2014, yaitu:

Tabel 2. Pemetaan Skala Urusan Pemerintahan Daerah Provinsi dan Daerah Kabupaten/Kota yang Hilang pada UU Pemda 2014 yang Disandingkan dengan Rezim UU Pemda 2004

\begin{tabular}{|c|c|c|c|c|}
\hline No. & Nama Urusan & Nama Sub Urusan & $\begin{array}{l}\text { Tingkat } \\
\text { Kewilayahan } \\
\text { yang Hilang }\end{array}$ & Keterangan \\
\hline 1. & $\begin{array}{l}\text { Bidang } \\
\text { Pendidikan }\end{array}$ & Akreditasi & $\begin{array}{l}\text { Provinsi dan } \\
\text { Kabupaten }\end{array}$ & $\begin{array}{l}\text { Pada rezim UU Pemda } 2004 \\
\text { akreditasi merupakan sub sub } \\
\text { bidang, dimana provinsi dan } \\
\text { kabupaten masih memiliki } \\
\text { kewenangan. }\end{array}$ \\
\hline 2. & $\begin{array}{l}\text { Bidang } \\
\text { Perumahan dan } \\
\text { Kawasan } \\
\text { Permukiman }\end{array}$ & $\begin{array}{l}\text { Perumahan dan } \\
\text { Kawasan } \\
\text { Permukiman } \\
\text { Kumuh }\end{array}$ & $\begin{array}{l}\text { Pemerintah } \\
\text { Pusat dan } \\
\text { Provinsi }\end{array}$ & $\begin{array}{l}\text { Pada rezim UU Pemda } 2004 \\
\text { terdapat sub sub bidang } \\
\text { permukiman kumuh/nelayan } \\
\text { dimana pemerintah pusat dan } \\
\text { provinsi masih memiliki } \\
\text { kewenangan. }\end{array}$ \\
\hline \multirow[t]{2}{*}{3.} & $\begin{array}{l}\text { Bidang } \\
\text { Pertanahan }\end{array}$ & $\begin{array}{l}\text { Pengadaan Tanah } \\
\text { untuk Kepentingan } \\
\text { Umum }\end{array}$ & Kabupaten & $\begin{array}{l}\text { Pada rezim UU Pemda } 2004 \\
\text { terdapat sub bidang pengadaan } \\
\text { tanah untuk kepentingan } \\
\text { umum, dimana Kabupaten } \\
\text { masih memiliki beberapa } \\
\text { bentuk kewenangan. }\end{array}$ \\
\hline & & Tanah Ulayat & $\begin{array}{l}\text { Pemerintah } \\
\text { Pusat }\end{array}$ & $\begin{array}{l}\text { Pada rezim UU Pemda } 2004 \\
\text { terdapat sub bidang penetapan } \\
\text { tanah ulayat, dimana } \\
\text { pemerintah pusat masih } \\
\text { memiliki kewenangan. }\end{array}$ \\
\hline
\end{tabular}




\begin{tabular}{|c|c|c|c|c|}
\hline & \multirow{2}{*}{$\begin{array}{l}\text { Tanah Kosong } \\
\\
\text { Izin Membuka } \\
\text { Tanah }\end{array}$} & \multirow{2}{*}{$\begin{array}{l}\text { Pemerintah } \\
\text { Pusat } \\
\text { Pemerintah } \\
\text { Pusat dan } \\
\text { Provinsi }\end{array}$} & \multirow{2}{*}{$\begin{array}{l}\text { Pada rezim UU Pemda } 2004 \\
\text { terdapat sub bidang } \\
\text { pemanfaatan dan penyelesaian } \\
\text { masalah tanah kosong, dimana } \\
\text { pemerintah pusat masih } \\
\text { memiliki kewenangan. } \\
\text { Pada rezim UU Pemda } 2004 \\
\text { terdapat sub bidang dengan } \\
\text { izin membuka tanah, dimana } \\
\text { pemerintah pusat dan provinsi } \\
\text { masih memiliki kewenangan. } \\
\text { Khusus tingkat provinsi } \\
\text { dijelaskan kewenangannya } \\
\text { berbentuk tugas pembantuan. }\end{array}$} \\
\hline & & & & \\
\hline \multirow[t]{2}{*}{4.} & \multirow[t]{2}{*}{$\begin{array}{l}\text { Bidang } \\
\text { Administrasi } \\
\text { Kependudukan } \\
\text { dan Pencatatan } \\
\text { Sipil }\end{array}$} & $\begin{array}{l}\text { Pendaftaran } \\
\text { Penduduk }\end{array}$ & Provinsi & $\begin{array}{l}\text { Pada rezim UU Pemda 2004, } \\
\text { terdapat sub bidang } \\
\text { pendaftaran penduduk, dimana } \\
\text { provinsi masih memiliki } \\
\text { kewenangan. }\end{array}$ \\
\hline & & Pencatatan Sipil & Provinsi & $\begin{array}{l}\text { Pada rezim UU Pemda 2004, } \\
\text { terdapat sub bidang } \\
\text { pendaftaran sipil, dimana } \\
\text { provinsi masih memiliki } \\
\text { kewenangan. }\end{array}$ \\
\hline 5. & $\begin{array}{l}\text { Bidang } \\
\text { Pemberdayaan } \\
\text { Masyarakat dan } \\
\text { Desa }\end{array}$ & $\begin{array}{l}\text { Administrasi } \\
\text { Pemerintahan } \\
\text { Desa }\end{array}$ & $\begin{array}{l}\text { Pemerintah } \\
\text { Pusat dan } \\
\text { Provinsi }\end{array}$ & $\begin{array}{l}\text { Pada rezim UU Pemda } 2004, \\
\text { terdapat sub sub bidang } \\
\text { administrasi pemerintahan } \\
\text { desa dan kelurahan, dimana } \\
\text { pemerintah pusat dan provinsi } \\
\text { memiliki kewenangan. }\end{array}$ \\
\hline 6. & $\begin{array}{l}\text { Bidang } \\
\text { Pengendalian } \\
\text { Penduduk dan } \\
\text { Keluarga } \\
\text { Berencana }\end{array}$ & $\begin{array}{l}\text { Standardisasi dan } \\
\text { Sertifikasi }\end{array}$ & $\begin{array}{l}\text { Provinsi dan } \\
\text { Kabupaten }\end{array}$ & $\begin{array}{l}\text { Pada rezim UU Pemda 2004, } \\
\text { tidak ada sub bidang maupun } \\
\text { sub sub bidang yang secara } \\
\text { implisit menyebutkan tentang } \\
\text { standardisasi dan sertifikasi } \\
\text { yang terkait bidang keluarga } \\
\text { berencana dan keluarga } \\
\text { sejahtera. }\end{array}$ \\
\hline 7. & $\begin{array}{l}\text { Bidang } \\
\text { Perhubungan }\end{array}$ & Penerbangan & Provinsi & $\begin{array}{l}\text { Pada rezim UU Pemda 2004, } \\
\text { terdapat sub bidang } \\
\text { perhubungan udara, dimana } \\
\text { provinsi masih memiliki } \\
\text { kewenangan. }\end{array}$ \\
\hline 8. & $\begin{array}{l}\text { Bidang } \\
\text { Penanaman } \\
\text { Modal }\end{array}$ & $\begin{array}{l}\text { Kerja Sama } \\
\text { Penanaman Modal }\end{array}$ & $\begin{array}{l}\text { Provinsi dan } \\
\text { Kabupaten }\end{array}$ & $\begin{array}{l}\text { Pada rezim UU Pemda } 2004 \text {, } \\
\text { terdapat sub sub bidang kerja } \\
\text { sama penanaman modal, } \\
\text { dimana provinsi dan kabupaten } \\
\text { masih memiliki kewenangan. }\end{array}$ \\
\hline
\end{tabular}




\begin{tabular}{|c|c|c|c|c|}
\hline \multirow[t]{2}{*}{9.} & \multirow[t]{2}{*}{ Bidang Statistik } & Statistik Dasar & $\begin{array}{l}\text { Provinsi dan } \\
\text { Kabupaten }\end{array}$ & \multirow{2}{*}{$\begin{array}{l}\text { Pada rezim UU Pemda 2004, } \\
\text { terdapat sub bidang statistik } \\
\text { dasar, dimana provinsi dan } \\
\text { kabupaten memiliki masih } \\
\text { kewenangan. } \\
\text { Pada rezim UU Pemda 2004, } \\
\text { terdapat sub bidang statistik } \\
\text { sektoral, dimana pemerintah } \\
\text { pusat masih memiliki } \\
\text { kewenangan. }\end{array}$} \\
\hline & & Statistik Sektoral & $\begin{array}{l}\text { Pemerintah } \\
\text { Pusat }\end{array}$ & \\
\hline \multirow[t]{2}{*}{10.} & \multirow[t]{2}{*}{$\begin{array}{l}\text { Bidang } \\
\text { Persandian }\end{array}$} & $\begin{array}{l}\text { Akreditasi dan } \\
\text { Sertifikasi }\end{array}$ & $\begin{array}{l}\text { Provinsi dan } \\
\text { Kabupaten }\end{array}$ & $\begin{array}{l}\text { Pada rezim UU Pemda 2004, } \\
\text { akreditasi tidak disebutkan } \\
\text { secara implisit sebagai sub } \\
\text { bidang ataupun sub sub } \\
\text { bidang, namun disebutkan } \\
\text { dalam masih bentuk konkrit } \\
\text { pembagian urusan, dimana } \\
\text { provinsi dan kabupaten masih } \\
\text { memiliki kewenangan. }\end{array}$ \\
\hline & & Analisis Sinyal & $\begin{array}{l}\text { Provinsi dan } \\
\text { Kabupaten }\end{array}$ & $\begin{array}{l}\text { Pada rezim UU Pemda } 2004 \text {, } \\
\text { tidak ada sub bidang, sub sub } \\
\text { bidang, ataupun keterangan } \\
\text { konkrit dalam penjabaran } \\
\text { pembagian urusan yang } \\
\text { menyebutkan analisis sinyal. }\end{array}$ \\
\hline \multirow[t]{2}{*}{11.} & \multirow[t]{2}{*}{$\begin{array}{l}\text { Bidang } \\
\text { Kebudayaan }\end{array}$} & Perfilman Nasional & $\begin{array}{l}\text { Provinsi dan } \\
\text { Kabupaten }\end{array}$ & $\begin{array}{l}\text { Pada rezim UU Pemda 2004, } \\
\text { terdapat sub sub bidang } \\
\text { perfilman, dimana provinsi dan } \\
\text { kabupaten masih memiliki } \\
\text { kewenangan. }\end{array}$ \\
\hline & & Warisan Budaya & $\begin{array}{l}\text { Provinsi dan } \\
\text { Kabupaten }\end{array}$ & $\begin{array}{l}\text { Pada rezim UU Pemda 2004, } \\
\text { tidak disebutkan sub bidang } \\
\text { maupun sub sub bidang } \\
\text { tentang warisan budaya, } \\
\text { namun penjabarannya dapat } \\
\text { ditemukan dalam kewenangan } \\
\text { pemerintah pusat, provinsi, } \\
\text { dan kabupaten. }\end{array}$ \\
\hline \multirow[t]{2}{*}{13.} & \multirow[t]{2}{*}{$\begin{array}{l}\text { Bidang Kelautan } \\
\text { dan Perikanan }\end{array}$} & $\begin{array}{l}\text { Pengolahan dan } \\
\text { Pemasaran }\end{array}$ & Kabupaten & $\begin{array}{l}\text { Pada rezim UU Pemda 2004, } \\
\text { terdapat sub bidang } \\
\text { pengolahan dan pemasaran, } \\
\text { dimana kabupaten masih } \\
\text { memiliki kewenangan. }\end{array}$ \\
\hline & & $\begin{array}{l}\text { Karantina Ikan, } \\
\text { Pengendalian } \\
\text { Mutu dan } \\
\text { Keamanan Hasil } \\
\text { Perikanan }\end{array}$ & $\begin{array}{l}\text { Provinsi dan } \\
\text { Kabupaten }\end{array}$ & $\begin{array}{l}\text { Pada rezim UU Pemda 2004, } \\
\text { tidak ada sub bidang maupun } \\
\text { sub sub bidang karantina ikan, } \\
\text { pengendalian mutu, dan } \\
\text { keamanan hasil perikanan, } \\
\text { namun disebutkan dalam }\end{array}$ \\
\hline
\end{tabular}




\begin{tabular}{|c|c|c|c|c|}
\hline 14. & $\begin{array}{l}\text { Bidang } \\
\text { Pertanian }\end{array}$ & Varietas Tanaman & $\begin{array}{l}\text { Provinsi dan } \\
\text { Kabupaten }\end{array}$ & $\begin{array}{l}\text { Pada rezim UU Pemda 2004, } \\
\text { terdapat sub sub bidang } \\
\text { perlindungan varietas, dimana } \\
\text { provinsi dan kabupaten masih } \\
\text { memiliki kewenangan. }\end{array}$ \\
\hline \multirow[t]{4}{*}{15.} & \multirow[t]{4}{*}{$\begin{array}{l}\text { Bidang } \\
\text { Kehutanan }\end{array}$} & $\begin{array}{l}\text { Perencanaan } \\
\text { Hutan }\end{array}$ & $\begin{array}{l}\text { Provinsi dan } \\
\text { Kabupaten }\end{array}$ & $\begin{array}{l}\text { Bentuk-bentuk penjabaran } \\
\text { perencanaan hutan } \\
\text { sebagaimana dimaksud dalam } \\
\text { UU Pemda } 2014 \text {, dipisahkan } \\
\text { menjadi beberapa sub bidang } \\
\text { pada rezim UU Pemda } 2004 .\end{array}$ \\
\hline & & Pengelolaan Hutan & Kabupaten & $\begin{array}{l}\text { Bentuk-bentuk penjabaran } \\
\text { pengelolaan hutan } \\
\text { sebagaimana dimaksud dalam } \\
\text { UU Pemda 2014, dipisahkan } \\
\text { menjadi beberapa sub bidang } \\
\text { pada rezim UU Pemda } 2004 .\end{array}$ \\
\hline & & $\begin{array}{l}\text { Pendidikan dan } \\
\text { Pelatihan, } \\
\text { Penyuluhan dan } \\
\text { Pemberdayaan } \\
\text { Masyarakat di } \\
\text { Bidang Kehutanan }\end{array}$ & Kabupaten & $\begin{array}{l}\text { Bentuk-bentuk penjabaran } \\
\text { urusan pendidikan dan } \\
\text { pelatihan, penyuluhan dan } \\
\text { pemberdayaan masyarakat di } \\
\text { bidang kehutanan sebagaimana } \\
\text { dimaksud dalam UU Pemda } \\
2014 \text {, dipisahkan menjadi } \\
\text { beberapa sub bidang pada } \\
\text { rezim UU Pemda 2004. Dalam } \\
\text { beberapa sub bidang tersebut, } \\
\text { ada yang kewenangannya } \\
\text { dimiliki kabupaten sebelumnya, } \\
\text { ada yang sedari awal tidak } \\
\text { memiliki. }\end{array}$ \\
\hline & & $\begin{array}{l}\text { Pengawasan } \\
\text { Hutan }\end{array}$ & $\begin{array}{l}\text { Provinsi dan } \\
\text { Kabupaten }\end{array}$ & $\begin{array}{l}\text { Pada rezim UU Pemda 2004, } \\
\text { terdapat sub bidang } \\
\text { pengawasan bidang kehutanan, } \\
\text { dimana provinsi dan kabupaten } \\
\text { memiliki kewenangan. }\end{array}$ \\
\hline 16. & $\begin{array}{l}\text { Bidang } \\
\text { Perdagangan }\end{array}$ & $\begin{array}{l}\text { Sarana Distribusi } \\
\text { Perdagangan }\end{array}$ & $\begin{array}{l}\text { Pemerintah } \\
\text { Pusat }\end{array}$ & $\begin{array}{l}\text { Pada rezim UU Pemda } 2004 \text {, } \\
\text { terdapat sub bidang sarana dan } \\
\text { prasarana, dimana pemerintah } \\
\text { pusat memiliki kewenangan. }\end{array}$ \\
\hline
\end{tabular}

Sumber: Hasil Pengolahan Data Penulis, 2014. 
Berpijak dari pemetaan di atas, dapat disimpulkan bahwa sejatinya pemerintah daerah kabupaten/kota tidak kehilangan urusan pemerintahan, namun hanya kehilangan sub urusan pemerintahan. Secara umum keberadaan Lampiran UU Pemda 2014 telah menyerap atau mengabsorpsi Peraturan Pemerintah Nomor 38 Tahun 2007 tentang Pembagian Urusan Pemerintahan Antara Pemerintah, Pemerintahan Daerah Provinsi, dan Pemerintahan Daerah Kabupaten/Kota (PP Pembagian Urusan) dengan beberapa bentuk perubahan, sehingga materi muatannya mengatur mengenai pembagian urusan pemerintahan. Dengan demikian, sejatinya PP Pembagian Urusan mutatis mutandis sudah tidak memiliki kekuatan hukum mengikat karena secara substansinya telah diatur dalam UU Pemda 2014.

Meskipun tidak ada pembatalan PP Pembagian Urusan dan tidak mungkin suatu undang-undang secara eksplisit menyatakan mencabut peraturan pemerintah, namun berdasarkan pada asas lex superiori derogat legi inferiori maka PP Pembagian Urusan akan dinegasikan dengan Lampiran UU Pemda 2014. Hal tersebut dikarenakan Lampiran UU Pemda 2014 melakukan perubahan pembagian urusan yang sebelumnya dimiliki oleh pemerintahan pada level tertentu. Lampiran UU Pemda 2014 juga melakukan simplifikasi urusan. Maksudnya, apabila dalam PP Pembagian Urusan banyak urusan yang dirinci menjadi beberapa sub-sub urusan atau beberapa urusan, kemudian dalam rezim UU Pemda 2014 hal tersebut dipadatkan menjadi satu urusan.

\section{Implikasi Distribusi Urusan Pemerintahan terhadap Hubungan Pusat dan Daerah}

Dalam konteks praktis distribusi urusan pemerintahan melalui desentralisasi dalam kerangka NKRI menghadapi permasalahan, yakni antara lain: (1) penyerahan urusan pemerintahan oleh pemerintah pusat kepada daerah-daerah otonom; (2) perimbangan keuangan antara pemerintah pusat dan pemerintah daerah; dan (3) kemampuan daerah otonom untuk mengatur dan mengurus urusan-urusan pemerintahan yang telah diserahkan oleh pemerintah pusat kepadanya menjadi urusan rumah tangga daerah. ${ }^{32}$ Dengan permasalahan yang muncul sebagai akibat penerapan desentralisasi di atas, sudah seharusnya pemerintah pusat sebagai pemegang kekuasaan mutlak pemerintahan membentuk desain distribusi urusan pemerintahan yang tepat dan terarah sesuai dengan susunan negara kesatuan yang menjadi konsensus bentuk negara Indonesia.

Pilihan untuk menjadi negara kesatuan yang menganut sistem desentralisasi semata dalam upaya mendekatkan pelayanan publik kepada rakyat, relatif tidak memberikan dampak signifikan bagi perkembangan daerah. Ketika desentralisasi dipilih berarti terjadi distribusi urusan yang semula dipegang oleh pemerintah pusat

\footnotetext{
32 Soehino, Op.cit., hlm. 177.
} 
beralih menjadi domain pemerintahan daerah. Desentralisasi yang secara simultan melahirkan otonomi daerah tidak sepatutnya hanya dimaknai sebagai strategi untuk mengelola hubungan kewenangan antara pemerintah pusat dan pemerintahan daerah. Desentralisasi yang sejatinya juga memperalihkan urusan pemerintahan juga harus secara jernih dikaitkan dengan kewenangan sebagai alas pelaksanaan urusan. Tentu saja konsep kewenangan dalam otonomi daerah tidak bisa didangkalkan atau ditukar pengertiannya dengan urusan, ${ }^{33}$ namun demikian harus diakui bahwa di dalam urusan-urusan pemerintahan tertentu itulah terdapat kewenangan-kewenangan yang bisa dilakukan oleh daerah, khususnya berkaitan dengan perencanaan, pengorganisasian, pelaksanaan, penganggaran, dan evaluasi. ${ }^{34}$

Distribusi urusan yang conditio sine qua non serta kewenangan di dalamnya membawa problematika tersendiri dalam kerangka hubungan antara pemerintah pusat dan pemerintahan daerah. Sebagaimana telah dijelaskan oleh Soehino di atas, ${ }^{35}$ potensi permasalahan dari distribusi urusan dari pemerintah pusat kepada pemerintahan daerah pun terjadi dalam konteks NKRI.

Pertama, pola distribusi urusan pemerintahan. Distribusi urusan dari pemerintah pusat kepada pemerintahan daerah secara spesifik diatur dalam UU Pemda 2014 terdiri atas urusan pemerintahan absolut, urusan pemerintahan konkuren, dan urusan pemerintahan umum. ${ }^{36}$ Namun demikian, dalam UU Pemda 2014 seolah mendangkalkan implikasi dari distribusi urusan hanya terkait pada hubungan keuangan antara pemerintah pusat dengan pemerintah daerah. Hal tersebut dibuktikan dengan tidak adanya lagi konsekuensi distribusi urusan dari pemerintah pusat yang melahirkan hubungan antara pemerintah pusat dan daerah, yang meliputi hubungan wewenang, keuangan, pelayanan umum, pemanfaatan sumber daya alam, dan sumber daya lainnya sebagaimana diatur dalam UU Pemda 2004. ${ }^{37}$ Padahal hubungan keuangan sejatinya hanyalah konsekuensi dari adanya hubungan kewenangan yang lahir dari distribusi urusan pemerintahan.

Lebih spesifik dalam konteks distribusi urusan pemerintahan, terdapat dua pola utama dalam intergovernmental task sharing, yaitu: (1) pola general competence (otonomi luas), yang mana urusan-urusan yang dijalankan pemerintah pusat bersifat limitatif, sedangkan sisanya (residu) menjadi urusan daerah; dan (2) pola ultra vires, urusan-urusan daerah ditentukan secara limitatif sedangkan sisanya ada pada pemerintah pusat. ${ }^{38}$ Indonesia secara eksplisit menerapkan general

\footnotetext{
33 Tri Ratnawati, et.al., Hubungan Kewenangan Antara Pemerintah Pusat dan Daerah dalam Otonomi Daerah di Indonesia: Peluang, Kendala, dan Implikasi, Jakarta: Pusat Penelitian Politik LIPI (P2P-LIPI), 2003, hlm. 15.

34 Ibid.

${ }^{35}$ Soehino, Loc. cit.

${ }^{36}$ Pasal 9 ayat (1) UU Pemda 2014.

37 Pasal 2 ayat (4) dan (5) UU Pemda 2004.

38 Tri Ratnawati, et.al., Loc.cit. Lihat juga dalam Direktorak Jenderal Otonomi Daerah Departemen Dalam Negeri,
} 
competence, dengan adanya pengaturan mengenai urusan yang menjadi domain pemerintah pusat, yaitu: (a) politik luar negeri; (b) pertahanan; (c) keamanan; (d) yustisi; (e) moneter dan fiskal nasional; dan (f) agama. ${ }^{39}$

Urusan yang didistribusikan kepada daerah merupakan hasil penyapihan urusan yang menjadi domain pemerintah pusat, sehingga dalam pelaksanaan urusan pemerintah pusat tersebut masih dimungkinkan adanya dekonsentrasi maupun tugas pembantuan kepada pemerintah daerah. ${ }^{40}$ Sedangkan di luar urusan yang menjadi domain pemerintah pusat merupakan urusan pemerintahan daerah, yaitu urusan pemerintahan wajib dan urusan pemerintahan pilihan yang keduanya termasuk dalam klasifikasi urusan pemerintahan konkuren. ${ }^{41}$ Setiap urusan yang didistribusikan kepada pemerintahan daerah disertai dengan pendanaan (money follows function $)^{42}$ untuk melaksanakan urusan pemerintahan tersebut. ${ }^{43}$ Walaupun telah ditentukan secara spesifik porsi urusan yang menjadi domain dari pemerintah pusat, namun berdasarkan Lampiran UU Pemda 2014 pemerintah pusat tetap turut serta melaksanakan urusan yang telah dilimpahkan kepada pemerintahan daerah. ${ }^{44}$ Inkonsistensi pengaturan inilah yang melahirkan permasalahan dalam hubungan kewenangan antara pemerintah pusat dan daerah dalam kerangka otonomi daerah.

Kedua, perimbangan keuangan antara pemerintah pusat dan pemerintah daerah. Problematika selanjutnya yang sering muncul dalam konteks desentralisasi adalah permasalahan perimbangan keuangan atau desentralisasi fiskal. Hal tersebut senada dengan pendapat Dennis A. Rondinelli yang menyatakan bahwa desentralisasi adalah "authority to plan, make decisions (finance), or manage public functions and these, under decentralization, have to be transfered to the lower levels of government". ${ }^{45}$ Dalam bahasa yang lebih sederhana, desentralisasi merupakan transfer tanggung jawab dan pendapatan dari pemerintah pusat ke daerah. Argumentasi tersebut dikuatkan oleh Gangadhar Jha dan Nimish Jha yang menyebutkan: ${ }^{46}$

\footnotetext{
Pokok-Pokok Pikiran Konsepsi Otonomi Daerah, Jakarta: Departemen Dalam Negeri, 2002, hlm. 13.

39 Pasal 9 ayat (2) jo Pasal 10 ayat (1) UU Pemda 2014.

40 Pasal 10 ayat (2) lihat juga Pasal 19 ayat (1) UU Pemda 2014.

41 Pasal 9 ayat (3) jo Pasal 11 ayat (1) UU Pemda 2014.

42 Konsepsi 'money follows function' digunakan untuk menghubungkan antara desentralisasi kewenangan dengan pembiayaan desentralisasi, yang berarti bahwa kewenangan yang diserahkan kepada daerah harus diikuti dengan pembiayaan yang sesuai dengan besarnya beban kewenangan tersebut. Normatifikasi konsepsi 'money follows function' diatur dalam Undang-Undang Nomor 33 Tahun 2004 tentang Perimbangan Keuangan antara Pemerintah Pusat dan Pemerintahan Daerah (UU Perimbangan Keuangan).

43 Pasal 279 UU Pemda 2014.

44 Pasal 9 ayat (3) jo. Pasal 13 UU Pemda 2014.

45 Dennis A. Rondinelli, "Government Decentralization in Comparative Perspective: Theory and Practice in Developing Countries", International Review of Administrative Sciences, Volume 47, Nomor 2, 1980, hlm. 133 145.

46 Gangadhar Jha dan Nimish Jha, “Centralized Decentralization - Overview of Local Governance in two Countries (Iraq and Bhutan)", Urban World, Volume 1, Nomor 2, Juli -September 2007, hlm. 3.
} 
"The instrumentalities of decentralization includes (i) fiscal decentralization (revenue assignment not only in terms of devolving of local tax and non-tax instruments but an autonomy to set the rates), (ii) institutional capacity for effective tax administration, (iii) rational inter-government fiscal relations based on a well-designed transfer system, (iv) system of local government accountability, (v) participatory structures and processes at the local level, and (vi) institutional incentives. Successful operation of fiscal decentralization is largely contingent on addressing these imperatives."

Hal tersebut meneguhkan bahwa permasalahan yang riskan timbul dalam praktik desentralisasi adalah permasalahan perimbangan keuangan antara pusat dan daerah.

Dalam konteks Indonesia, pengaturan perimbangan keuangan tersebut diatur dalam UU Nomor 33 Tahun 2004 tentang Perimbangan Keuangan antara Pemerintah Pusat dan Pemerintahan Daerah (UU Perimbangan Keuangan) yang mengenalkan konsepsi 'money follows function'. Konsepsi inilah yang kemudian sering disalahartikan antara nomenklatur 'fungsi' dan 'urusan'. Para birokrat daerah berpikir bahwa semakin banyak 'urusan' sama dengan semakin banyak 'fungsi', sehingga akan memperbesar perimbangan keuangan kepada daerah. Padahal, maksud dari konsepsi 'money follows function' bukanlah soal banyak atau sedikitnya 'urusan', melainkan 'fungsi' yang dapat dijalankan oleh daerah untuk menjalankan suatu 'urusan' tertentu.

Distribusi urusan yang diikuti dengan distribusi pendanaan sebagaimana konsepsi 'money follows function' menjadikan desentralisasi seolah dipersempit menjadi sekedar permasalahan perimbangan keuangan antara pusat dan daerah. Desentralisasi kewenangan memang tidak dapat dilepaskan dari desentralisasi fiskal. Dengan logika tersebut, setiap urusan yang didistribusikan oleh pemerintah pusat tidak akan dapat dilaksanakan dengan maksimal oleh pemerintahan daerah tanpa adanya distribusi pendanaan pula. Walaupun distribusi urusan tidak dapat dilepaskan dari permasalahan distribusi pendanaan, namun dalam mendesain pola desentralisasi tidak dapat difokuskan semata pada permasalahan pemberian dana. Hal utama yang harus diperhatikan adala bagaimana distribusi urusan pemerintahan mampu membuat daerah mandiri dan tidak semata-mata tergantung pada pendanaan yang diberikan oleh pemerintahan pusat.

Ketiga, kemampuan daerah otonom untuk mengatur dan mengurus urusanurusan pemerintahan yang telah didistribusikan oleh pemerintah pusat. Potensi permasalahan ini sebenarnya merupakan titik sentral permasalahan dalam hal distribusi urusan. Ketidakmampuan daerah dalam melaksanakan urusan tentu tidak dapat diselesaikan begitu saja dengan perimbangan keuangan sebagaimana dibahas pada uraian sebelumnya. Permasalahan kemampuan daerah dalam 
melaksanakan urusan pemerintahan terkait erat dengan governability ${ }^{47}$ yang tentu tidak dapat diselesaikan hanya dengan pendanaan dari pemerintah pusat. Peningkatan kapasitas dan kapabilitas aparat penyelenggara pemerintahan daerah menjadititik sentral yang harus dibenahi.

Hal tersebut sejalan dengan pemikiran Mohit Bhattacharya yang menyatakan bahwa desentralisasi dan pengembangan kapasitas aparatur penyelenggara pemerintahan daerah bagaikan dua sisi mata uang yang tidak terpisahkan. Bhattacharya menyebutkan bahwa "Human development and decentralization are almost like twins; one is concerned with 'humanizing' development discourse beyond conventional economism; the other relates to the location and institutionalization of development." ${ }^{48}$ Untuk itu, penyelesaian permasalahan ini tergantung pada aspek desain pola distribusi urusan dari pemerintah pusat kepada pemerintahan daerah.

\section{Penutup}

Berdasarkan pembahasan di atas, terlihat masih terdapat permasalahan dalam konteks pengaturan distribusi urusan pemerintahan dari pusat kepada daerah. Hal tersebut diperumit dengan keberadaan UU Desa yang contraditio in propositum dengan tujuannya untuk memberikan kejelasan status dan kepastian hukum atas desa dalam sistem ketatanegaraan NKRI. ${ }^{49}$ Ketaatan dalam memaknai terminologi urusan pemerintahan menjadi yang penting untuk diteguhkan kembali. Pada sisi yang lain, pola distribusi urusan pemerintahan dalam politik hukum desentralisasi di Indonesia secara simultan melahirkan otonomi daerah tidak sepatutnya hanya dimaknai sebagai strategi untuk mengelola hubungan kewenangan antara pemerintah pusat dan pemerintahan daerah. Desentralisasi yang sejatinya mendistribusikan urusan harus secara jernih dikaitkan dengan kewenangan sebagai alas pelaksanaan urusan. Tentu saja konsep kewenangan dalam otonomi daerah tidak bisa didangkalkan atau ditukar pengertiannya dengan urusan yang kemudian hanya sekedar dimaknai dengan hubungan keuangan sebagaimana rezim UU Pemda 2014. Namun demikian, harus diakui bahwa di dalam urusan-urusan pemerintahan tertentu itulah terdapat kewenangan-kewenangan yang bisa dilakukan oleh daerah, khususnya berkaitan dengan perencanaan, pengorganisasian, pelaksanaan, penganggaran, dan evaluasi.

Implikasi pola distribusi urusan terhadap hubungan kewenangan antara pemerintah pusat dan daerah dalam kerangka otonomi luas yang memperhatikan keberagaman dan kekhususan daerah menimbulkan permasalahan-permasalahan

\footnotetext{
47 Dengan Human Development Index yang dikembangkan United Nations Development Programme (UNDP) digunakan untuk mengukur praktik good governance dengan melihat perkembangan kemanusiaan (human progress). Lebih lanjut lihat dalam Pratikno, "Good Governance dan Governability", Jurnal IImu Sosial dan IImu Politik, Volume 8, Nomor 3, Maret 2005, hlm. 242.
} 
yang terjadi dalam konteks praktik distribusi urusan melalui desentralisasi dalam kerangka NKRI, antara lain: (1) distribusi urusan pemerintahan oleh pemerintah pusat kepada daerah-daerah otonom; (2) perimbangan keuangan antara pemerintah pusat dan pemerintah daerah; dan (3) kemampuan daerah otonom untuk mengatur dan mengurus urusan-urusan pemerintahan yang telah didistribusikan oleh pemerintah pusat kepadanya menjadi urusan rumah tangga daerah.

\section{Daftar Pustaka}

\section{Buku}

Bagir Manan, Perjalanan Historis Pasal 18UUD 1945, Uniska, Jakarta, 1993.

Direktorat Jenderal Otonomi Daerah Departemen Dalam Negeri, Pokok-Pokok Pikiran Konsepsi Otonomi Daerah, Departemen Dalam Negeri, Jakarta, 2002.

F. Soegeng Istanto, Beberapa Segi Hubungan Pemerintah Pusat dan Daerah dalam Negara Kesatuan Indonesia, Karyaputera, Yogyakarta, 1971.

Jimly Asshiddiqie, Konstitusi dan Konstitusionalisme, Konstitusi Press, Jakarta, 2006. Juniarto, Perkembangan Pemerintah Lokal, Alumni, Bandung, 1967.

M. Solly Lubis, Pergeseran Garis Politik dan Perundang-undangan Mengenai Pemerintah Daerah, Alumni, Bandung, 1983.

Ni'matul Huda, Otonomi Daerah: Filosofi, Sejarah Perkembangan dan Problematika, Pustaka Pelajar, Yogyakarta, 2005.

Pratikno, et.al., Policy Brief Menata Ulang Desain Desentralisasi Indonesia, Program Pascasarjana S2 Politik dan Pemerintahan, Jurusan Politik dan Pemerintahan, Fakultas IImu Sosial dan IImu Politik, Universitas Gadjah Mada, Yogyakarta, 2010.

Soehino, Hukum Tata Negara Perkembangan Otonomi Daerah, BPFE, Yogyakarta, 2004.

Tim Penyusun, Kamus Bahasa Indonesia, Pusat Bahasa Departemen Pendidikan Nasional, Jakarta, 2008.

Tri Ratnawati, et.al., Hubungan Kewenangan Antara Pemerintah Pusat dan Daerah dalam Otonomi Daerah di Indonesia: Peluang, Kendala, dan Implikasi, Pusat Penelitian Politik LIPI (P2P-LIPI), Jakarta, 2003. 


\section{Dokumen Lain}

Bhattacharya, Mohit, "Decentralization - The Conceptual and Institutional Dimensions", Urban World, Juli 2004.

Jha, Gangadhar dan Nimish Jha, "Centralized Decentralization - Overview of Local Governance in Two Countries (Iraq and Bhutan)", Urban World, Volume 1, Nomor 2, Juli-September 2007.

Pratikno, "Good Governance dan Governability", Jurnal IImu Sosial dan IImu Politik, Volume 8, Nomor 3, Maret 2005.

Rondinelli, Dennis A., "Government Decentralization in Comparative Perspective:

Theory and Practice in Developing Countries", International Review of Administrative Sciences, Volume 47, Nomor 2, 1980.

\section{Dokumen Hukum}

Undang-Undang Dasar Negara Republik Indonesia Tahun 1945.

Undang-Undang Nomor 32 Tahun 2004 tentang Pemerintahan Daerah.

Undang-Undang Nomor 33 Tahun 2004 tentang Perimbangan Keuangan antara Pemerintah Pusat dan Pemerintahan Daerah.

Undang-Undang Nomor 6 Tahun 2014 tentang Desa.

Undang-Undang Nomor 23 Tahun 2014 tentang Pemerintahan Daerah.

Putusan Mahkamah Konstitusi Nomor 006/PUU-IV/2006 perihal Pengujian Undang-Undang Nomor 27 Tahun 2004 tentang Komisi Kebenaran dan Rekonsiliasi terhadap Undang-Undang Dasar Negara Republik Indonesia Tahun 1945. 